\title{
Replicating Hofstede in Jordan: Ungeneralized, Reevaluating the Jordanian Culture
}

\author{
Mahmud Alkailani (Corresponding author) \\ Head of Marketing Department \\ Faculty of Economics and Administrative Studies, Yarmouk University \\ Irbid, Jordan \\ Tel: 962-77-9936-8893 E-mail: mkailani@yu.edu.jo
}

Islam A. Azzam

Trainer and Consultant in Organizational Leadership

Department of Management, Faculty of Economics and Administrative Studies, Yarmouk University

Irbid, Jordan

Tel: 962-79-735-0656 E-mail: alazzam@yu.edu.jo

Abdel Baset Athamneh

Director of refugees, Displaced Persons \& Forced Migration Studies Center, Yarmouk University

Irbid, Jordan

Tel: 962-79-535-1358 E-mail: Athamneh71@yu.edu.jo

Received: October 19, 2011

Accepted: February 24, $2012 \quad$ Published: April 1, 2012

doi:10.5539/ibr.v5n4p71

URL: http://dx.doi.org/10.5539/ibr.v5n4p71

\begin{abstract}
Hofstede was credited with completing the largest cross-cultural study applicable to international management theory and a review of the literature indicates that the dimensions identified by Hofstede capture the essence of many dimensions and value orientations proposed by other researchers. The effect of culture on people's life is so great that it will even affects the motives and choices of people's behavior. The aim of the study is to update the Hofstede cultural value dimensions. We argue that scores (findings) obtained by Hofstede in his previous studies conducted in Arab countries and then generalized to Jordanian culture are not scientifically valid. This study replicates Hofstede's study with data obtained from students studying for their master degrees in different universities in Jordan. Throughout the history of studying national cultures, a number of researchers, through their intense investigation of cultures, explored different cultural frameworks. This paper begins by reviewing the literature on culture and cultural frameworks. In the section after that, a replication of Hofstede's study was conducted and findings were obtained. The final section concludes with a discussion of findings, and why findings obtained differ from those found earlier by Hofstede himself in previous research.
\end{abstract}

Keywords: Jordan, Culture, Cultural dimensions, Hofstede, Arab Countries, Individualism, Collectivism, Power distance, Uncertainty avoidance, Masculinity, Femininity

\section{Culture Defined}

The definition of culture and what is meant by culture has been open to debate and differences of interpretation (Ayoun, 2008). Culture is a complex universe including knowledge, beliefs, arts, morals, laws, customs, and any capabilities and habits a member of society can obtain (Taylor, 1974). Culture can be learned and shared (Hofstede, 1980), is the social heritage and life regulator (Chang, 1987), continues to grow and change; and every field of human life is related to it (Soares, Farhangnher \& Shohmes, 2008). In short, culture is the sum of all treasures created by human beings, and the generic term for all life demonstrated by society (Chang \& Chwang, 2005). 
Cultures can be understood as systems of symbols and meanings that even their creators contest, that lack fixed boundaries, that are constantly in flux, and that interact and compete with one another (Swider, 1986). It is a complex construct that can be studied on different levels; organizational, regional, and national (Hofstede, 1998).

\section{Cultural Frameworks}

The concept of culture can help us understand the puzzle of human diversity that is so dominant in public discussions today about multicultural societies Marketing and business researchers, on the other hand, view national culture more as a dynamic process affecting a wide range of behaviors, particularly those relating to buying and consumption (Chuang \& Chang, 2005).

Triandis (1994) illustrates that culture cannot be separated from the individual; it is not a system of abstract values that exists independently of individuals. Neither can culture be separated from its historical context; culture is to society what memory is to an individual. It includes the things that have worked in the past, shared beliefs, attitudes, norms, roles, and values found among speakers of a particular language who live during the same historical period in a specific geographic region. These shared elements of subjective culture are usually transferred from generation to generation. Language, time, and place, therefore, help define culture.

Kluckhohn (1969) claims that the essential core of culture consists of patterns, explicit and implicit, behavior acquired and transmitted by symbols, constituting the distinctive achievements of human groups, including their embodiment in artifacts; traditional (i.e. historically derived and selected) ideas and especially their attached values. Culture systems may, on the one hand, be considered products of action and on the other, conditional elements of future action.

In his try to elaborate on the effect of values in shaping national cultures, Hofstede (1997) proposed two aspects of values that must be distinguished: (1) values as guiding principles in life, and (2) values as preference for one mode of behavior over another. The distinction refers to the desirable and the desired, or what people think ought to be desired and what people actually desire - how people think the world ought to be versus what people want for themselves. Mead (1994) defined values as the abstract ideas about what a group believes to be good, right and desirable, Rokeach (1973) sees a value as an enduring belief that one mode of conduct or end-state of existence is preferable to an opposing mode of conduct, or end-state of existence.

Another important part that shapes culture is attitudes. De Mooij (2002) views attitudes as a lasting general evaluation of people, objects and issues. Equally important, are attitudes which are expressed values that dispose a person to act or to react in a certain way toward something. Values refer to a single belief of a very specific kind, as opposed to an attitude that refers to an organization of several beliefs around a specific object or situation (Adler, 1989). Furthermore, Kotler (2005) thinks that attitudes put people into a frame of mind of liking or disliking things, of moving towards or away from them.

\section{Components of Culture and Cultural Frameworks}

Some researchers (e.g., Hofstede, 1991; Barkow et al., 1992; Adler, 1998; chang \& chwang, 2005) tried to study components of culture more deeply. Barkow et al., (1992) distinguished three kinds of culture: Meta culture, evoked culture, and epidemiological culture.

The conceptual background of culture implies that values are among the important factors that form the basis of a given culture. Values are shared among people living in the same generation and are transmitted from one generation to another by the socialization process. These historically learned values provide a basis for the formation of a culture and a standard for socially acceptable norms which affect people's formation of attitudes. (KO, 1994). Similarly, Kluckhon $(1961,1969)$ assumed that values hold the key to understanding a culture. Values are considered by many as the most essential component in defining and studying culture. In most of the culture studies, reviewed herein, the fundamental component of culture reflected is its value system; hence values were the analytic focus of cultural assessment.

Values are at the core of Hofstede's model of culture. These values form the most hidden layer of culture. Values as such represent the ideas that people have about how things "ought to be". As such, Hofstede also emphasizes the assumption that values are strongly influencing behavior.

Beyond the values, Hofstede (1991) describes three levels of culture that are more clearly observable; rituals, heroes, and symbols. The differences that exist among societies inspired many researchers (e.g., Strodbeck, 1964; Hall et al., 2004; De Mooij, 1998; Triandis, 1995; Hofstede, 1980; Scwartz, 1994; Adler, 1998). Furthermore, Hofstede (1998) argued that the cultural orientation of a society reflects the complex interaction of values, attitudes and behaviors displayed by its members. Individuals express the normative qualities of culture through the values they hold about life and the world around them. These values, in turn, affect their attitudes about the form of behavior considered most appropriate and effective in any given situation. 
Kluckhohn (1961) assumed that cultures shape and influence individuals and provide distinct answers to the same questions. This insight inspired Hofstede to search for cultural solutions to organizational problems. Hofstede (1991) found that there are three factors that, at least to some degree, determine the behavior of a person in the workplace such as, national culture, occupational culture, and organizational culture. Hofstede (1997) believes that culture influences behavior through its manifestations: values, heroes, rituals, and symbols. These are the forms through which culturally-determined knowledge is stored and expressed. Thus, each cultural group possesses different cultural manifestation.

On the other side, Schwartz (1994) tried to establish an alternative approach for deriving cultural dimensions of work-related values. In his study, a set of 56 value questions were used. Respondents rated each value for importance as "a guiding principle in their own life". From these 56 values, 10 individual level value types were derived. The technique used was smallest space analysis. A consequence of this technique is that the value types are not independent. The 10 value types were organized on two basic bipolar dimensions. Each pole constitutes a higher-order value type that combines two or more of the 10 types. One dimension opposes Openness to Change (Self-Direction and Stimulation) to Conservation (Conformity, Tradition and Security). The other dimension opposes Salt-transcendence (Universalism and Benevolence) to Self-Enhancement (Achievement and Power). Although this structure applied to individual values, it was used as a hypothesis for the structure of culture-level values. Analysis across 47 cultures established that of the 56 values, 45 had nearly equivalent meanings across cultures (Schwartz, 1994).

Hofstede (1991) introduced new cultural dimensions to the field of cultural studies; Power Distance, Uncertainty Avoidance, Individualism and Collectivism, Masculinity vs. Femininity, and long-term vs. short-term orientation. The following represent a thorough investigation of these dimensions.

Power Distance: Power-distance is the extent to which the less powerful members of institutions and organizations within a country expect and accept that power is distributed unequally (Hofstede 1997). It ranges in value from zero, for a culture with a small power-distance, to about 100, for a culture with a large power distance. In cultures with large power distance, everybody has his/her rightful place in society, there is respect for old age, and status is important to show power. In cultures with small power distance, people try to look younger than they are and powerful people try to look less powerful (De Mooij \& Hofstede, 2002).

\subsection{Uncertainty-Avoidance}

Uncertainty-avoidance is the degree to which employees feel threatened by unknown or uncertain situations. Uncertainty-avoidance is scored from zero, indicating a culture with the weakest uncertainty avoidance, to 100 , indicating a culture with the strongest uncertainty avoidance (Hofstede, 1997). In cultures of strong uncertainty avoidance, there is a need for rules and formality to structure life and competence is a strong value resulting in belief in experts. In weak uncertainty avoidance cultures there is a strong belief in the generalist. Moreover, in weak uncertainty avoidance cultures, people tend to be more innovative and entrepreneurial. In cultures of strong uncertainty avoidance, people tend to be better groomed than in cultures of weak uncertainty avoidance because it is one way to face a threatening world. For example, purity in food is an important need in cultures of high uncertainty avoidance (De Mooij \& Hofstede, 2002).

\subsection{Individualism/Collectivism}

The dimension of individualism refers to the extent to which the ties between individuals are loose (Hofstede, 1997). In individualist cultures, people look after themselves and their immediate family only. In collectivist cultures, people belong to groups that look after them in exchange for loyalty. In individualist cultures, the identity is in the person; in collectivist cultures, identity is based in the social network to which one belongs. In individualist cultures there is more explicit, verbal communication; in collectivist cultures communication is more implicit (De Mooij \& Hofstede, 2002).

Similarly, Triandis (1995) defined collectivism as a social pattern that consists of individuals who see themselves as an integral part of one or more collectives or in-groups, such as family and co-workers. People who are more collectivist are often motivated by norms and duties imposed by the in-group, give priority to the goals of the in-group, and try to emphasize their connectedness with the in-group. He defines individualism as a social pattern that consists of individuals who see themselves as autonomous and independent. People who are more individualistic are motivated by their own preferences, needs, and rights, give priority to their personal goals, and emphasize a rational analysis of their relationships with others (Triandis, 1994). Additionally, in individualist cultures, people often ignore the potential negative consequences of their buying behavior preferring to focus on the positive consequences of their actions and on their own feelings and goals. This may not be true for people from collectivist cultures, who are more likely to focus on the potential negative consequences of their behavior and the effect of their actions on in-group members (Triandis, 1995). 


\subsection{Masculinity versus Femininity}

In masculine cultures the dominant values are achievement and success performance and achievement are important. Status is important to show success. In contrast, the dominant values in feminine cultures are caring for others and quality of life. Feminine cultures have a people orientation, small is beautiful, and status is not very important. In masculine cultures there is substantial role differentiation between males and females whereas, in feminine cultures there is less role differentiation (De Mooij \& Hofstede, 2005). The cultural characteristic of masculinity refers to societies where gender roles are clearly divided. Men are expected to be assertive, tough, and focused on material success. Women are expected to be "modest, tender, and concerned with the quality of life (Hofstede, 1997).

\subsection{Long Term Orientation and Short Term Orientation}

Long term orientation and short term orientation have two different characteristics. Long term directions societies, in the one hand, are characterized by persistence, ordering relationships by status and observing this order, thrift, and having a sense of shame. On the other hand, People from short term societies are characterized by personal steadiness and stability, protecting the 'face', respect or tradition and reciprocation of greetings, favors, and gifts (Note 1). Long term oriented cultures found in East Asia value acceptance of change, perseverance, thrift, and pursuit of peace of mind unlike the short term oriented cultures found in the Western world (De Mooij \& Hofstede, 2005).

Hofstede (1991) describes long term orientation as characterized by persistence, ordering relationships by status, and observing this order, thrift, and having a sense of shame. On the other hand, short term orientation is characterized by personal steadiness. Long term orientation tries to distinguish the difference in thinking between the East and West (long term demisnion, 2008). The extent to which a society exhibits a pragmatic, future-oriented perspective rather than a conventional historic or short term perspective is another component of long term orientation. Moreover, this dimension describes a society's "time horizon," or the importance attached to the future versus the past and present. In long term oriented societies, values include persistence (perseverance), ordering relationships by status, thrift, and having a sense of shame; in short term oriented societies, values include normative statements, personal steadiness and stability, protecting ones face, respect for tradition, and reciprocation of greetings, favors, and gifts.

\section{Replication of Hofstede's Cultural Dimensions in Jordan}

Hofstede's original data were derived from matched populations of employees from national subsidiaries of one multinational firm, IBM. More than 116,000 questionnaires were administered in 72 countries and in 20 languages between 1967 and 1973 . The results were originally validated against some 40 cross-cultural studies from a variety of disciplines, and have been extended by Hofstede (2001). Hofstede states that these dimensions differentiate national cultures around the world and he provides ratings on these dimensions for many countries as characterized below (Hofstede's cultural dimensions, 2008).

Hofstede (1980, 1991, 1997) study was replicated in different settings; in information technology (Harvey, 1997), in economic dynamics and institutional stability (Tang \& Koveos, 2008), in work related values (Kirkman, Lowe \& Gibson, 2006), in international marketing studies (Soares, Farhangmehr \& Shoham, 2007), in public anxiety (Arrindell et al., 2004), in facework studies (Merkin, 2006), in transformational leadership (Ergeneli, Gohar \& Temirbekova, 2007), and in crossvergence and cultural tendencies (Kelley, MacNab \& Worthley, 2006).

Hofstede's work remains the most comprehensive study of cultural differences with putative relevance to marketers (Holden, 1999) and his five dimensions are the most widely accepted as a solid framework for conducting national culture research (Hambrick \& Brandon, 1988). When researchers discuss culture in an international context, the name of Hofstede is invariably invoked and his dimensions are applied as an authority of holy writ (Holden, 1999) and most cultural models done after Hofstede clarify and support Hofstede's dimensions and can most relate back to Hofstede's dimensions (Smith, Dugan \& Trompenaars, 1996). In addition to the fact that Hofstede's cultural dimensions have substantial face validity (Kolman et al., 2003), Hofstede's framework is still considered the most robust measure of national culture (Gong et al., 2007).

Hofstede (1980, 1997) studied some Arab countries (Egypt, Iraq, Kuwait, Libya, UAE and Lebanon) and generalized findings obtained to all Arab countries including Jordan. Craig and Douglas (2005) pointed out that one of the misleading recommendations researchers do is to generalize findings obtained from one culture to other cultures without careful consideration of major differences exist among these cultures. Even though Egypt, Saudi Arabia, Iraq and UAE are similar to Jordan in terms of some important aspects (religion and language), these countries are still far less similar from each other with regard to GDP, disposable income, social life, government intervention, educational institutions, level of literacy and economic infrastructure. (Central Intelligence Agency (CIA), 2009). Tang and Koveos (2008) argue that changes in economic conditions are the source of cultural dynamics, while the endurance of institutional characteristics provides the foundation for cultural stability. They also found that national wealth, 
measured by GDP per capita, has a curvilinear relationship with individualism, long-term orientation, and power distance scores. Therefore, Hofstede's generalization of findings taken from these countries and applied at Jordan should be revised with careful consideration of differences mentioned. According to Hofstede's $(1980,1997)$ typology, the Arab countries, to which Jordan belongs, were classified as having high power distance (80), high uncertainty avoidance (68), a collectivist culture (91 on Individualism), and a masculine culture (53).

The aim of the study is to update the Hofstede cultural value dimensions. We argue that scores obtained by Hofstede in his previous studies conducted in Arab countries and then findings generalized to Jordanian culture is not scientifically valid. This study replicates Hofstede's study with data obtained from students studying for their master degrees in different universities in Jordan. To operationalize culture, Hofstede (1980) have used matched samples to eliminate the effect of other factors. This study replicates Hofstede's study in the same way; using a matched sample on as many characteristics as possible (age and education). A total of 795 graduate students have participated in this study of which 375 were males and 420 were females.

\section{Methodology}

Through an empirical study using the mixed method approach, qualitative and quantitative content analysis, this study used the Hofstede Value to stay in alignment with similar studies. Hofstede Value Survey Module 94 (VSM 94) was used to measure national culture dimensions. Hofstede survey has shown to have acceptable convergent, discriminant and external validities (Swierczek, 1991; Hoppe, 1990; Holden, 1999; Lee, Anne \& Geoffrey 2006; Hambrick \& Brandon, 1988; Smith \& Bond, 1998; Gong et. al, 2007). Hofstede Survey used covered four cultural dimensions; Power distance, Individualism, masculinity and uncertainty avoidance.

Individualism Index (IDV): to calculate the (IDV) index, the following equation was used:

$$
\mathrm{IDV}=-50 \mathrm{~m}(01)+30 \mathrm{~m}(02)+20 \mathrm{~m}(04)-25 \mathrm{~m}(08)+130
$$

In which, $\mathrm{m}(01)$ is the mean score for question 01 , etc. The index normally has a value between 0 (strongly collectivist) and 100 (strongly individualist), but values below 0 and above 100 are technically possible. Questions included in the test are:

- Have sufficient time for your personal or family life.

- Have good physical working conditions (good ventilation and lighting adequate work space, etc.).

- Have security of employment.

- Have an element of variety and adventure in the job.

Answers to these questions range from 5; of utmost importance to 1; of very little or no importance.

Masculinity Index (MAS): to calculate the (MAS) index, the following equation was used:

$$
\text { MAS }=+60 \mathrm{~m}(05)-20 \mathrm{~m}(07)+20 \mathrm{~m}(15)-70 \mathrm{~m}(20)+100
$$

In which $\mathrm{m}(05)$ is the mean score for question 05 , etc. The index normally has a value between 0 (strongly feminine) and 100 (strongly masculine), but values below 0 and above 100 are technically possible. The following questions were involved in analysis:

- Work with people who cooperate well with one another.

- Have an opportunity for advancement to higher level jobs.

Answers to these questions range from 5; of utmost importance to 1; of very little or no importance. The following questions were used:

Respondents were also asked to show to what extent do they agree or disagree with each of the following statements and to circle one of the options that describe their opinion using a scale ranges from 5; strongly agree to 1; strongly disagree. The following questions were used:

- Most people can be trusted.

- When people have failed in life it is often their own fault.

Uncertainty Avoidance Index (UAI): to calculate the (UAI) index, the following equation was used:

$$
\mathrm{UAI}=+25 \mathrm{~m}(13)+20 \mathrm{~m}(16)-50 \mathrm{~m}(18)-15 \mathrm{~m}(19)+120
$$

In which $\mathrm{m}$ (13) is the mean score for question 13, etc. The index normally has a value between 0 (weak Uncertainty Avoidance) and 100 (strong Uncertainty Avoidance), but values below 0 and above 100 are technically possible. 
Respondents were asked to indicate to what extent do you agree or disagree with each of the statements mentioned. Answers range from 1; strongly disagree and 5; strongly agree. These statements include the following:

- Competition between employees usually does more harm than good.

- A company's or organization's rules should not be broken not even when the employee thinks it is in the company's best interest.

- One can be a good manager without having precise answers to most questions that subordinates may raise about their work.

Respondents were also asked to answer how often do they feel nervous or tense at work. Scale for this question ranges from 1 ; never to 5 ; always feeling nervous.

Power Distance Index (PDI): to calculate the (PDI) index, the following formula was used:

$$
\text { PDI }=-35 m(03)+35 m(06)+25 m(14)-20 m(17)-20
$$

In which $\mathrm{m}(03)$ is the mean score for question 03 , etc. The index normally has a value between 0 (small Power Distance) and 100 (large Power Distance), but values below 0 and above 100 are technically possible. Respondents were asked to think of an ideal job, disregarding their present job, if they have one. In choosing an ideal job, they were asked to answer how important would it be to them. The scale ranges from 5; of utmost importance to 1; of very little or no importance. The following questions were used:

- Have a good working relationship with your direct superior.

- Be consulted by your direct superior in his/her decisions.

- An organization structure in which certain subordinates have two bosses should be avoided at all costs.

- How frequently, in your experience, are subordinates afraid to express disagreement with their superiors? This question was measured through a scale ranges from 1 , which indicates very seldom, and 5 , which indicate very frequently.

Table1 shows Mean scores per question for all cultural dimensions proposed by Hofstede. Based on these mean scores, the following cultural index values were calculated.

Insert Table 1 Here

New indices were calculated for Jordanian culture as follows:

Power Distance Index (PDI)

$$
\text { PDI }=-35 \mathrm{~m}(03)+35 \mathrm{~m}(06)+25 \mathrm{~m}(14)-20 \mathrm{~m}(17)-20
$$

New calculated Jordan Index $=-35(1.78)+35(2.16)+25(3.05)-20(3.09)-20=7.75$

Individualism Index (IDV)

$$
\mathrm{IDV}=-50 \mathrm{~m}(01)+30 \mathrm{~m}(02)+20 \mathrm{~m}(04)-25 \mathrm{~m}(08)+130
$$

New calculated Jordan Index $=-50(2.79)+30(1.71)+20(1.72)-25(1.96)+130=27.2$

Masculinity Index (MAS)

$$
\text { MAS }=+60 \mathrm{~m}(05)-20 \mathrm{~m}(07)+20 \mathrm{~m}(15)-70 \mathrm{~m}(20)+100
$$

New calculated Jordan Index $=60(1.80)-20(2.01)+20(3.19)-70(2.58)+100=51$

Uncertainty Avoidance Index (UAI)

$$
\mathrm{UAI}=+25 \mathrm{~m}(13)+20 \mathrm{~m}(16)-50 \mathrm{~m}(18)-15 \mathrm{~m}(19)+120
$$

New calculated Jordan Index $=25(2.6)+20(3.28)-50(1.86)-15(3.17)+120=110$

\section{Discussion}

This research aims to contribute to recent research on Hofstede cultural dimensions by testing the robustness of the Hofstede model, in view of the fact that the social scientific work requires many replications in order to establish a database of facts (Hunter, 2011). Hofstede's national culture dimensions are considered as a base for understanding the influence of national culture on people's behavior. In his book "Culture and organizations: Software of the mind", Hofstede (2005) has grouped all Arab countries in one cluster and called them "Arabic-speaking countries" and compared them to other parts of the world. Hofstede (1980) findings documented that all Arab countries share same scores and accordingly share similar cultural values despite the fact that Hofstede only studied some of them (Egypt, 
Iraq, Kuwait, Libya, UAE and Lebanon) and generalized findings obtained to all other Arab countries, including Jordan.

This study utilizes the original cultural dimensions developed by Hofstede (1980) to calculate cultural indices in different countries. Hofstede's scales has been applied in different studies across cultures to understand the behavior of people across cultures, and thus appeared to have an acceptable convergent, discriminant and external validities (Kolman et al., 2003; Swierczek, 1991; Hoppe, 1990; Holden, 1999; Lee, Anne \& Geoffrey 2006; Hambrick \& Brandon, 1988; Smith \& Bond, 1998; Gong et al., 2007).

A closer look into the results of this study reveals some interesting insights. First, the hofstede dimensions for Arab cultures, Studied previously by hofestede (Egypt, Iraq, Kuwait, Libya, UAE and Lebanon), appeared to show similar scores for Jordanians on the dimensions of Masculinity (51) and Individualism (27.7), and a difference on the dimensions of uncertainty avoidance (110) and power distance (7.75). Differences in scores found prove the fact that Arab countries differ in their value orientations (Barakat, 1993; Al-Nashmi \& Syd Zin, 2011).

Second, findings show similarities in both Masculinity and individualism. According to Hofstede, Arab countries score 53 on Masculinity index, while the Jordanian Culture scores 51 which validates that Jordan shares same Masculine characteristics as other Arab countries. A high score in Masculinity indicates that the culture places high value on competitiveness and accumulation of wealth; and a very discrete gender role. Although Arab countries differ from each other in terms of wealth, Hoftede himself reported that the Masculinity- femininity dimension is not related to national wealth (Hofstede, 2005). Third, Jordan culture also appeared to be a collectivist culture with a score of 27.7 on individualism which is close to what Hofstede reported about Arab countries (38). In collectivist societies, people emphasize cooperation and relationship building, trustworthiness, solidarity with others and being conservatives. A quick review of the Arab history and religion of Islam, a reader can notice that Arab countries share these characteristics as a direct effect of religion and the Arabs' history before Islam.

Fourth, as for uncertainty avoidance scores, this study found that Jordanian culture score (7.75) which differs from other Arab countries score (80) reported previously by Hofstede. This study proves that the Jordanian Culture is low on power distance unlike other Arab countries. From my experience with Jordanians and other rab nationals, I found the Jordanian culture to represent a "new version" of modern cultures where employees are young, not afraid of disagreeing with their bosses, and are consulted in decisions related to their work. Hofstede (2005) reported that cultures with low power distance observe adaptability and carefulness. Hofstede (2005) also reported that education level, and occupation has a significant effect on the level of power distance inside societies. Jordanians are famous of having a thirst for knowledge and education which is unique. The ministry of education in Jordan initiated many reform movements related to modernizing education and encouraged Jordanian institutions to become world leaders to earn better accreditation (Khasawneh, 2011). A Jordanian family is proud of having member of a family going to university for either an undergraduate or a graduate education. Despite the limited resources Jordanians possess compared with their Arab counterparts, Jordan has a better education index than other Arab countries (.87) (Arab statistics, 2011) and the public expenditure on education approaches $20.6 \%$ of total government expenditures. As a result of these progressing figures of the quality of teaching, Jordan is one of Arab countries with the highest skilled workers (Athamneh, 2008). This might explain the low power distance reported for Jordanians in this study which matches the finding reported by Hofstede (2005) in his latest study where he found that cultures with unskilled and semiskilled workers showed the highest power distance index.

In conclusion we argue that Hofstede's $(1980,1991,2005)$ assumption that people who grow up in the same place will share similar views about life does not apply to his findings about Arab cultures and thus his generalization made to Jordanian culture is not validated. In addition Jordan was not represented in Hofstede's researches and this contradicts with his latest finding where Hofstede (2005) reported that Arab countries differ among themselves and the country with more representation in the study is more likely to show different scores. This finding is also validated by the new work of Al-Nashmi and Syd Zin (2011) who argued that Hofstede findings do not represent a true generalization. They also proposed that Hofstede should have divided the Arab region into different territories according to the cultural proximity (e.g. Yemen, Iraq, and all the Arab Gulf countries as one territory; Syria, Lebanon, Jordan, and Palestine as another one; Egypt as a separate territory; Arab West as a territory; and Sudan, Djibouti, and Somalia as a separate territory). Al-Nashmi and Syd Zin (2011) also found that different Arab people from different Arab countries are not the same in terms of their national culture values.

Based on the findings obtained in this study and the discussion followed, researchers recommend that Hofstede's dimensions should be tested in every individual country. In addition, and due to the fast changing environmental factors specially those closely related to culture and society, researchers recommend a continuous revision and update of Hofstede's scores over time. 


\section{References}

Adler, N. J. (1983). Cross-cultural management research: The ostrich and the trend. The Academy of Management Review, 8(2), 223-232. http://dx.doi.org/10.5465/AMR.1983.4284725

Al-Nashmi, M. M., \& Syd Zin, S. A. R. (2011). Variation in communication satisfaction of academic staff in universities in Yemen depending on national culture. Cross Cultural Management: An International Journal, 18(1), 87-105. http://dx.doi.org/10.1108/13527601111104313

Arrindell, W., Eisemann, M., Oei, T., Caballo, V., Sanavio, E., Sica, C., . . Ende, J. (2004). Phobic anxiety in 11 nations: part II. Hofstede's dimensions of national cultures predict national-level variations. Personality and Individual Differences, 37(3), 627-643. http://dx.doi.org/10.1016/j.paid.2003.11.002

Athamneh, A. B., \& Zubi, B. (2008). Long-run macroeconomic impact of labor migration: An econometric analysis for the case of Jorda (1973-2004). Dirassat (Administrative Sciences), 25(2).

Ayoun, B., \& Moreo, P. (2008). Does national culture affect hotel managers' approach to business strategy?. International Journal of Contemporary Hospitality Management, 20(1), 7-18. http://dx.doi.org/10.1108/09596110810848532

Barkow, G., Cosmides, L., \& Tooby, J. (1992). The Adapted Mind: Evolutionary Psychology and the Generation of Culture. New York: Oxford Univ. Press.

Chung, E. (2001). Factors influencing purchase decisions of online apparel shoppers. Retrieved from ProQuest Dissertations \& Theses.

Craig, S., \& Douglas, S. (2005). International Marketing research (3rd ed.). NJ, USA: John wiley and sons.

De Mooij, G., \& Hofstede, G. (2002). Why marketers need a new concept of culture for the global knowledge economy. Journal of Retailing, 78, 61-69. http://dx.doi.org/10.1016/S0022-4359(01)00067-7

De Mooij, M. (2001). Convergence and divergence in consumer behavior: consequences for global marketing and advertising. (Unpublished doctoral dissertation). University of Navarra. http://dx.doi.org/10.1016/S00224359(01)00067-7

Dorthy, K. (1994). Teachers of the inner chambers: women and culture in seventeenth-century China. A google book. Education statistics in Jordan. (2011). Retrieved from www.Arabstats.org.

Ergeneli, A., Gohar, R., \& Temirbekova, Z. (2007). Transformational leadership: Its relationship to culture value dimensions. International Journal of Intercultural Relations, 31(6), 703-724. http://dx.doi.org/10.1016/j.ijintrel.2007.07.003

Gong, W., Lee, Z., \& Stump, R. (2007). Global internet and access: Cultural considerations. Asia pacific journal of marketing, 19(1), 57-74.

Hambrick, D. C., \& Brandon, G. L. (1988). Executive Values, In D.C. Hambrick (ed.).

Harvey, F. (1997). National cultural differences in theory and practice: Evaluating Hofstede's national cultural framework. Information Technology \& People, 10(2) 132-146. http://dx.doi.org/10.1108/09593849710174986

Hofested, G. Cultural dimensions. [online] Available: www.geert-hofstede.com.

Hofested, G. Long-term orientation. [online] Available www.geert-hofstede.com

Hofstede, G. (1983). The cultural relativity of organizational practices and theories. Journal of international business studies, 14(2), 75-89. http://dx.doi.org/10.1057/palgrave.jibs.8490867

Hofstede, G. (1985). The interaction between national and organizational value Systems. Journal of Management Studies, 32, 347-357. http://dx.doi.org/10.1111/j.1467-6486.1985.tb00001.x

Hofstede, G. (1991). Culture and Organizations: software of the mind. New York: McGraw-Hill.

Hofstede, G , (1993). Cultural constraint in management theories. Academy of Management Executive, 7(1), 81-92.

Hofstede, G. (1997). Cultures and organizations: Software of the mind. New York: McGraw Hill.

Hofstede, G. (1998). Attitudes, values and organizational culture: Disentangling the concepts. Organization studies, 19(3), 477-492. http://dx.doi.org/10.1177/017084069801900305

Hofstede, G., Dienes, E., Kolman, L., \& Noorderhaven, N. (2003). Cross-cultural differences in Central Europe. Journal of Managerial Psychology, 18(1), 76-88. http://dx.doi.org/10.1108/02683940310459600 
Holden, N. (2004). Why marketers need a new concept of culture for the global knowledge economy. International Marketing Review, 21(6), 563-572. http://dx.doi.org/10.1108/02651330410568015

Hoppe, M. (1990). A comparative study of country elites: international differences in work-related values and learning and their implications for management training and development. Retrieved from ProQuest Dissertations \& Theses.

Hoppe, M. (1993). The effects of national culture on the theory and practice of managing R\&D professionals abroad. R\&D Management Journal, 23(4), 313-325.

Kasawneh, S. (2011). Human Capital planning in higher education institutions: A strategic human resource development initiative in Jordan. International Journal of Educational Management, 25(6), 534-544. http://dx.doi.org/10.1108/09513541111159040

Kelley, L., MacNab, B., \& Worthley, R. (2006). Crossvergence and cultural tendencies: A longitudinal test of the Hong Kong, Taiwan and United States banking sectors. Journal of International Management, 12,(1), 67-84. http://dx.doi.org/10.1016/j.intman.2005.04.002

Kirkman, B., lowe, K., \& Gibson, B. (2006). A quarter century of Culture's Consequences: a review of empirical research incorporating Hofstede's cultural values framework. Journal of International Business Studies, 37, 285-320. http://dx.doi.org/10.1057/palgrave.jibs. 8400202

Kluckholn, C. (1951). The Study of Culture: The Policy Sciences. Stanford: Stanford University Press

Kluckhohn, C. (1969). Values and Value Orientations in the Theory of Action: Towards a General Theory of Action. Cambridge: Harvard University Press.

Kolman, L., Noorderhaven, N. G., Hofstede, G., \& Dienes, E. (2003). Cross-cultural differences in Central Europe. Journal of Managerial Psychology, 18(1), 76-88. http://dx.doi.org/10.1108/02683940310459600

Kotler, P., \& Armstrong, G. (2006). Principles of Marketing. Upper Saddle River: prentice Hall publishing company. Marinda, H., Menno, D., \& Steehouder, M. (2004). Cultural differences and usability evaluation: Individualistic and collectivistic participants compared. Technical Communication, 51(4), 489-503.

Mead, R. (1994). International Management: cross cultural dimensions. Oxford: Blackwell Business.

Merkin, R. (2006). Uncertainty avoidance and the facework: A test of the Hofested model. International Journal of intercultural relations, 30(2), 213-228. http://dx.doi.org/10.1016/j.ijintrel.2005.08.001

Nancy, A., \& Migel, C. (1989). In search of appropriate methodology: From outside the People's Republic of China looking. Journal of International Business Studie, 20(1), 61-67.

Rokeach, S. J. (1973). Values and violence: A test of the subculture of violence thesis. American Sociological Review, 38(6), 736-749.

Schwartz, S. (1994). Are there universal aspects in the structure and contents of human values?. Journal of Social Issues, 50(4), 19-45. http://dx.doi.org/10.1111/j.1540-4560.1994.tb01196.x

Seiddler, A. (1986). Culture in action: Symbols and strategies. American Sociological Review, 51(2), 273-286. http://dx.doi.org/10.2307/2095521

Smith, P., Dugan, S., \& Trompenaars, F. (1996). National culture and the values of organizational employees a dimensional analysis across 43 nations. Journal of Cross-Cultural Psychology, 27(2) 231-264. http://dx.doi.org/10.1177/0022022196272006

Soares, M., Farhangmehr, M., \& Shoham, A. (2007). Hofstede's dimensions of culture in international marketing studies. Journal of business research, 60(3), 277-284. http://dx.doi.org/10.1016/j.jbusres.2006.10.018

Strodbeck, F. (1964). Considerations of meta-method in cross-cultural studies. American Anthropologist, 66(3), 223-229. http://dx.doi.org/10.1525/aa.1964.66.3.02a00900

Swierczek, F. (1991). Leadership and culture: Comparing Asian managers. Leadership \& Organization Development Journal, 12(7), 3-10. http://dx.doi.org/10.1108/EUM0000000001165

Tang, L., \& Peter Koveo, E. (2008). A framework to update Hofstede's cultural value indices: economic dynamics and institutional stability. Journal of International Business Studies, 39, 1045-1063. http://dx.doi.org/10.1057/palgrave.jibs.8400399

Taylor, J. W. (1974). The role of risk in consumer behavior. Journal of Marketing, 38, 54-60. http://dx.doi.org/10.2307/1250198 
Triandis, H. (1994). Culture and social behavior. New York, NY, England: Mcgraw-Hill Book Company.

Trompenaars, A., \& Hampden, T. C. (1998). Riding the waves of culture: Understanding cultural diversity in global business (2nd ed.). New York: McGraw Hill.

\section{Notes}

Note 1. http://www.Clearlycultural.com

Table 1. New Mean Scores for Each Question Used in the Survey

\begin{tabular}{|c|c|c|c|}
\hline $\begin{array}{l}\text { Question's Number } \\
\text { in the survey }\end{array}$ & Question & Cultural dimension & $\begin{array}{l}\text { Mean } \\
\text { score }\end{array}$ \\
\hline Question 1 & Have sufficient time for your personal or family life. & Individualism & 2.7857 \\
\hline Question 2 & Have good physical working conditions (good ventilation). & Individualism & 1.7054 \\
\hline Question 3 & Have a good working relationship with your direct superior. & Power Distance & 1.7768 \\
\hline Question 4 & Have security of employment. & Individualism & 1.7232 \\
\hline Question 5 & Work with people who cooperate well with one another. & Masculinity & 1.7946 \\
\hline Question 6 & Be consulted by your direct superior in his/her decisions. & Power Distance & 2.1607 \\
\hline Question 7 & Have an opportunity for advancement to higher level jobs. & Masculinity & 2.0179 \\
\hline Question 8 & Have an element of variety and adventure in the job. & Individualism & 1.9643 \\
\hline Question 13 & How often do you feel nervous or tense at work? & Uncertainty Avoidance & 2.5982 \\
\hline Question 14 & $\begin{array}{l}\text { How frequently, in your experience, are subordinates afraid to } \\
\text { express disagreement with their superiors? }\end{array}$ & Power Distance & 3.0536 \\
\hline Question15 & Most people can be trusted. & Masculinity & 3.1875 \\
\hline Question16 & $\begin{array}{l}\text { One can be a good manager without having precise answers to } \\
\text { most questions that subordinates may raise about their work. }\end{array}$ & Uncertainty Avoidance & 3.2857 \\
\hline Question17 & $\begin{array}{l}\text { An organization structure in which certain subordinates have } \\
\text { two bosses should be avoided at all costs. }\end{array}$ & Power Distance & 3.0982 \\
\hline Question18 & $\begin{array}{l}\text { Competition between employees usually does more harm than } \\
\text { good. }\end{array}$ & Uncertainty Avoidance & 1.8571 \\
\hline Question19 & A company's or organization's rules should not be broken. & Uncertainty Avoidance & 3.1696 \\
\hline Question20 & When people have failed in life it is often their own fault. & Masculinity & 2.5804 \\
\hline
\end{tabular}

